\title{
SEXO OPRIMIDO: O ESQUECIMENTO DAS PARTICULARIDADES DO SEXO FEMININO DENTRO DO SISTEMA PRISIONAL
}

\section{MARIA RITA BORGES FERREIRA VELOSO}

Graduanda em Direito, modalidade integral, pela Escola Superior Dom Helder Câmara- Belo Horizonte -MG. E-mail: mariaritaborges18@gmail.com.

\section{CAIO AUGUSTO SOUZA LARA}

Mestre e Doutor em Direito pela Faculdade de Direito da Universidade Federal de Minas Gerais - UFMG. Professor da Escola Superior Dom Helder Câmara. Pesquisador Associado ao Programa RECAJ-UFMG - Acesso à Justiça e Solução de Conflitos. Secretário de Comunicação do Conselho Nacional de Pesquisa e Pósgraduação em Direito - CONPEDI. Belo Horizonte-MG. E-mail: caiolarabh@yahoo.com.br.

\section{RESUMO}

A falta de acesso a itens básicos dentro dos presídios femininos é característica intrínseca à quase totalidade das instituições carcerárias brasileiras. Ao realizar precisas analises sobre o tema, torna-se evidente não só a falta de estrutura física adequada dessas instituições, mas também o tamanho descaso das entidades públicas para com as detentas, que se manifesta por meio de inúmeros casos. Entre eles, tem-se: celas superlotadas, mal iluminadas e com pouca ventilação, baixa distribuição de itens de higiene pessoal, reduzido número de profissionais da saúde especialistas em questões ginecológicas, péssima qualidade dos alimentos fornecidos, que são servidos em quantidades insuficientes e, na maioria das vezes, estragados, além das constantes violências físicas e psicológicas às quais as presidiárias são submetidas. Tendo em vista tais situações, é perceptível o quanto o 


\section{Personalidade Acadêmica Homenageada:}

Raymundo Juliano Feitosa (Universidade Federal do Rio Grande do Norte - UFRN)

sexo feminino é tratado com desprezo pelo sistema prisional, a realidade e peculiaridade das mulheres são simplesmente esquecidas. Essas, além de não serem inseridas em estabelecimentos próprios, são, por muitas vezes, transferidas para antigas instituições prisionais masculinas. A partir disso, surge um questionamento: a mulher devido as peculiaridades de sua própria condição tem mais dificuldades dentro do sistema prisional? A partir das reflexões preliminares sobre o tema, é possível afirmar que elas são intensamente prejudicadas pelas políticas do sistema carcerário, pelo simples fato de serem mulheres. Elas sequer possuem acesso a itens de higiene pessoal, como papel higiênico e absorvente, na quantidade necessária, a exames ginecológicos e preventivos com regularidade, ou alas maternais para os cuidados com os recém-nascidos. Percebe-se que os presídios destinados às mulheres não foram construídos de forma adequada a recebê-las. Eles, em sua maioria, são criados como se fossem receber homens, o que demostra a defasagem, tanto da estrutura dos presídios femininos quanto das políticas públicas que são destinadas a eles, e que em suma prejudicam o cumprimento de penas, pelas presidiárias, de forma humanamente adequadas. Sendo assim, o objetivo geral do trabalho é analisar quais direitos das presas estão sendo violados no sistema prisional na cidade de Belo Horizonte-MG, e como tal fato implica no desrespeito à dignidade da pessoa humana e dificulta a ressocialização. A pesquisa que se propõe pertence à vertente metodológica jurídico-sociológica. No tocante ao tipo de investigação, foi escolhido, na classificação de Witker (1985) e Gustin (2010), o tipo jurídico-diagnóstico. O raciocínio desenvolvido na pesquisa será predominantemente dedutivo. De acordo com a técnica de análise de conteúdo, afirma-se que se trata de uma pesquisa teórica, o que será possível a partir da análise de conteúdo dos textos doutrinários, normas e demais dados colhidos na pesquisa. Como conclusão parcial da pesquisa, tem-se que - Estado apresenta um paradoxo em relação à Lei de Execução Penal (LEP), visto que em seu corpo normativo apresenta uma gama de direitos e deveres que possivelmente permitiriam a plena ressocialização das presas, e, no entanto, a realidade dos presídios se mostra inteiramente diferente daquela a qual se propôs em seu ordenamento. Os princípios constitucionais são constantemente desrespeitados dentro dessas instituições, contribuindo cada vez mais para o fortalecimento de 
Personalidade Acadêmica Homenageada:

Raymundo Juliano Feitosa (Universidade Federal do Rio Grande do Norte - UFRN)

facções criminosas e o crescente índice de criminalidade do país. Portanto, ter um olhar mais humano e preciso a respeito desse tema para que sejam propostas modificações nesse cenário degradante, é imprescindível para que os princípios mínimos de garantias e direitos dessas cidadãs sejam definitivamente desrespeitados.

PALAVRAS-CHAVE: Sistema Prisional; Gênero; Mulheres; Violação de Direitos.

\section{REFERÊNCIAS}

BRASIL. Constituição da República Federativa do Brasil de 1988. Disponível em: http://www.planalto.gov.br/ccivil_03/constituicao/constituicao.htm. Acesso em: 20 de maio 2019.

. Lei no 7210, de 11 de junho de 1984. Institui a Lei de Execução Penal. Disponível em: http://www.planalto.gov.br/ccivil_03/leis//7210.htm. Acesso em: 10 de maio 2019.

GUSTIN, Miracy Barbosa de Sousa; DIAS, Maria Tereza Fonseca. (Re)pensando a pesquisa jurídica: teoria e prática. 3a․ ed. Belo Horizonte: Del Rey, 2010.

MALUF, Marina; MOTT, Maria Lúcia. Recônditos do mundo feminino. In: NOVAIS, Fernando (Org.) História da vida privada no Brasil. v.3. São Paulo: Companhia das Letras, 1998, p.365-421.

QUEIROZ, Nana. Presos que menstruam. Rio de Janeiro: Editora Record, 2015.

SANTOS, Thandara. VITTO, Renato Campos Pinto. Ministério da Justiça. Departamento Penitenciário Nacional. Levantamento Nacional de Informações Penitenciárias Infopen Mulheres. 2014. p.5-19

SILVA, Ricardo Marcassa Ribeiro; KNOERR-SÉLLOS, Viviane Coêlho. O trabalho como instrumento da promoção da dignidade do preso. Revista Jurídica UNICURITIBA, v.01, n.38, p.136-158. 2015. Disponível em: https://docs.google.com/viewerng/viewer?url=http://revista.unicuritiba.edu.br/index.ph p/RevJur/article/viewFile/1269/828. Acesso em: 20 de maio 2019.

SIQUEIRA, Dirceu Pereira; PRETIS, Maria Eduarda Pires. Reserva do possível e os direitos sociais: Da previsão normativa a concretização. Revista Jurídica UNICURITIBA, Curitiba, v.01, n.46, p. 188-203. 2017. Disponível em: https://docs.google.com/viewerng/viewer?url=http://revista.unicuritiba.edu.br/index.ph p/RevJur/article/viewFile/2045/1322. Acesso em: 20 de maio 2019. 
Personalidade Acadêmica Homenageada:

Raymundo Juliano Feitosa (Universidade Federal do Rio Grande do Norte - UFRN)

VARELLA, Drauzio. Prisioneiras. São Paulo: Companhia das Letras, 2017.

WITKER, Jorge. Como elaborar uma tesis en derecho: pautas metodológicas y técnicas para el estudiante o investigador del derecho. Madrid: Civitas, 1985. 